\title{
The Temperature of Halite Crystallization in the Badenian Saline Basins, in the Context of Paleoclimate Reconstruction of the Carpathian Area
}

\author{
Anatoliy R. Galamay ${ }^{1}$ (D), Krzysztof Bukowski ${ }^{2, *} \mathbb{D}$, Igor M. Zinchuk ${ }^{1}$ and Fanwei Meng ${ }^{3}$ \\ 1 Institute of Geology and Geochemistry of Combustible Minerals N.A.S. of Ukraine, 79053 Lviv, Ukraine; \\ galamaytolik@ukr.net (A.R.G.); ig.zinchuk@ukr.net (I.M.Z.) \\ 2 Faculty of Geology, Geophysics and Environmental Protection, AGH University of Science and Technology, \\ 30059 Kraków, Poland \\ 3 State Key Laboratory of Paleobiology and Stratigraphy, Nanjing Institute of Geology and Paleontology, \\ Chinese Academy of Sciences, Nanjing 210008, China; fwmeng@nigpas.ac.cn \\ * Correspondence: buk@agh.edu.pl
}

check for updates

Citation: Galamay, A.R..;

Bukowski, K.; Zinchuk, I.M.;

Meng, F. The Temperature of Halite

Crystallization in the Badenian Saline

Basins, in the Context of Paleoclimate Reconstruction of the Carpathian

Area. Minerals 2021, 11, 831.

https://doi.org/10.3390/min11080831

Academic Editor: Francesco Dela Pierre

Received: 30 June 2021

Accepted: 27 July 2021

Published: 30 July 2021

Publisher's Note: MDPI stays neutral with regard to jurisdictional claims in published maps and institutional affiliations.

Copyright: (c) 2021 by the authors. Licensee MDPI, Basel, Switzerland. This article is an open access article distributed under the terms and conditions of the Creative Commons Attribution (CC BY) license (https:// creativecommons.org/licenses/by/ $4.0 /)$.

\begin{abstract}
Currently, fluid inclusions in halite have been frequently studied for the purpose of paleoclimate reconstruction. For example, to determine the air temperature in the Middle Miocene (Badenian), we examine single-phase primary fluid inclusions of the bottom halites (chevron and fullfaceted) and near-surface (cumulate) halites collected from the salt-bearing deposits of the Carpathian region. Our analyses showed that the temperatures of near-bottom brines varied in ranges from 19.5 to $22.0^{\circ} \mathrm{C}$ and 24.0 to $26.0^{\circ} \mathrm{C}$, while the temperatures of the surface brines ranged from 34.0 to $36.0^{\circ} \mathrm{C}$. Based on these data, such as an earlier study of lithology and sedimentary structures of the Badenian rock salts, the crystallization of bottom halite developed in the basin from concentrated and cooled near-surface brines of about $30 \mathrm{~m}$ depth. Our results comply with the data on the temperature distribution in the modern Dead Sea.
\end{abstract}

Keywords: Carpathians; Badenian; halite; fluid inclusions; homogenization temperature

\section{Introduction}

The Paratethys was a system of interconnected epicontinental seas linked with the Mediterranean and periodically with the Atlantic and Indian Oceans. That chain of basins existed in various configurations from the early Oligocene to the late Middle Miocene. Episodically, due to complex tectonic and/or glacio-eustatic processes, the marine gateways to open oceans were closed, and the hydrological exchange between different basins was restricted. Consequently, large hypersaline waters became the sources of regional-scale saline formations, developed from the Burdygalian to the Serravalian in the Carpathian area, the Red Sea, and the Middle East.

One of the most widespread salt formations was formed in the Middle Miocene (Badenian) during the Badenian Salinity Crisis (BSC) around 13.8 to 13.4 Ma [1]. Those Badenian salts can be found in modern Poland, Ukraine, Romania, Slovakia, Hungary, and Bosnia and Herzegovina. The stratigraphic position, radiometric ages of accompanying tuff layers, and similar lithology of salt deposits (rock salts with anhydrite and intercalation of terrigenous clays) allow for a general correlation of formations [2] and indicate homogeneous paleoclimatic conditions of salt basins in the Central Paratethys.

The carbon and oxygen isotopic composition and the $\mathrm{Mg} / \mathrm{Ca}$ ratio of calcareous shells of microfauna are some of the essential elements of the reconstruction of paleotemperature in ancient marine basins. However, the prohibited macrofaunal ecosystems during salt deposition do not allow for the application of the methods mentioned above to reconstruct paleoclimatic conditions. 
The fluid inclusions trapped in minerals provide information on temperature, pressure, and fluid composition correlated with various geologic processes [3]. Consequently, a standard research methodology has been developed to interpret data from fluid inclusions [3-7]. Therefore, fluid inclusions in halite increasingly attract researchers' attention as a source of direct data and information on the halite crystallization temperature [8-12].

This paper presents the temperatures of homogenization in single-phase fluid inclusions contained in halite originating from various cores and mine faces of rock salts in the Carpathian area. The results of the study were used to construct a model of saline sedimentation during the Badenian Salinity Crisis.

\section{Geological Setting}

The Badenian, the period equivalent to the Upper Langhian-Lower Serravalian, has traditionally been divided into three parts by Papp et al. [13]: Lower (Moravian), Middle (Wielician), and Upper (Kosovian) Badenian. This division took into account the evaporites of the Middle Badenian (Wielician). According to new chronostratigraphic data, e.g., [14], evaporites are classified as the Late Badenian formations.

Based on the radiometric dating of tuff layers in the Wieliczka salt mine, the evaporite deposition onset was $13.81 \pm 0.08 \mathrm{Ma}$ [1]. The records of the correlation with the oxygen isotope showed that the evaporites had been closely preceded by glacial event Mi-3b dated in the Mediterranean at $13.82 \pm 0.03 \mathrm{Ma}$ [15]. That coincidence in time strongly indicated that the formation of Badenian evaporites was caused mainly by a glacio-eustatic sea-level drop of $\sim 50-70 \mathrm{~m}[16,17]$, reflecting the restarting of Antarctic glaciation. That event probably ended with a restricted open-marine connection to the Mediterranean (Trans-Tethyan Trench), with the disconnection of the Eastern Paratethys (the Bârlad Strait), thereby trapping the saturated brine in the deep parts of the Central Paratethys Basins $[1,18,19]$. The entire event may have lasted $\sim 400,000$ years in the Carpathian area and ended before $13.32 \pm 0.07 \mathrm{Ma}$ ago [20]. The Central Paratethys returned to open-marine conditions, and the Eastern Paratethys remained more brackish [17,19]. According to other authors [21], reconnection to the open ocean occurred before ca. $13.06 \pm 0.11 \mathrm{Ma}$.

In the Central Paratethys Basin (Figure 1), evaporites accumulated in the Carpathian Foredeep Basin and its foreland [2,22], the Transylvanian Basin, e.g., [23,24], the Transcarpathian and East Slovakian Basins [25], the area of the Mid-Hungarian shear zone [26], and the Tuzla Basin in Bosnia and Herzegovina [27].

The Carpathian Foredeep developed during the Early and Middle Miocene as a peripheral flexural foreland basin in front of the advancing Carpathian front [32]. That basin can be subdivided into inner and outer sections [32-34]. Two Badenian evaporitic lithofacies are distinguished within those deposits: sulfate facies (gypsum and anhydrite) and chloride facies (rock salt rock with intercalations of claystone and anhydrite). The evaporites of sulfate facies are widespread in the outer part of the Carpathian Foredeep, and they partly cover the platform (Figure 1). They also occur in the Carpathian Foredeep Basin, from Moravia in the western Czech Republic, through southern Poland and western Ukraine, to the Ukrainian-Romanian borderland and Moldova [2]. The evaporites of chloride facies occur in the deepest sections of the outer foredeep basin, in a narrow zone extending along the Carpathian overthrust and under the Carpathian overthrust's nappes [22,35,36]. In the Polish range of the Carpathian Foredeep, the salt-bearing series of the Wieliczka Fm is very well recognized in the salt mines in Wieliczka and Bochnia, e.g., [22,35-41]. Samples of halite with an admixture of anhydrite were taken in the Wieliczka salt mine from different lithological varieties of rock salt (Table S1 in Supplementary Materials). 


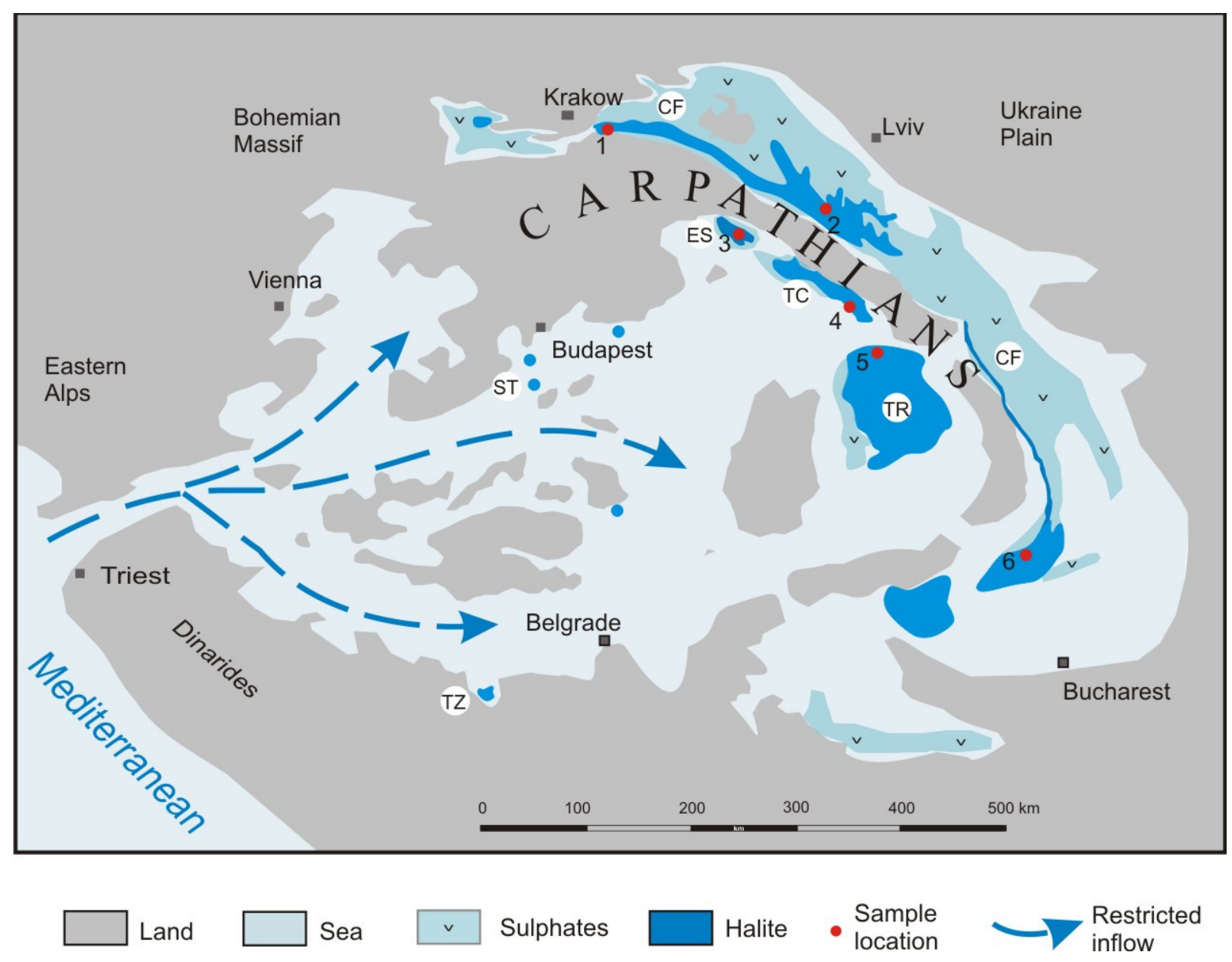

Figure 1. Paleogeographic map of sedimentation in the Badenian saline basins of the Central Paratethys, compiled after [25,26,28-31]. Locations of the investigated areas: 1—Wieliczka; 2-Hrynivka; 3-Zbudza; 4-Solotvyno; 5-Ocna Dej; 6-Slănic-Prahova. Salt basins: C.F.-Carpathian Foredeep; E.S.-East Slovakian Basin; T.C.-Transcarpathian Basin; T.R.-Transylvanian Basin; S.T.-Soltvadkert Trough; T.Z.-Tuzla Basin. Blue circles-boreholes with evaporites in the Soltvadkert Trough, after [26]. Square, gray symbols-main cities.

Evaporite deposits called 'Tyras suite' occur in the Ukrainian range of the Carpathian Foredeep (Badenian). The term 'suite' generally corresponds to a whole formation, but it is poorly defined with less complex stratigraphy [42]. In the outer zone of the foredeep, the salt-bearing sediments occur between the villages of Korshiv, Kolomiya, Kosiv, Zabolotiv of the Ivano-Frankivsk area, and Bohorodchany and Bratkivtsiv. The salt facies has also been found in the northeastern part of the inner foredeep zone: Kalush, Hrinivka, Drohobych, and Sambor regions [43]. Those evaporites (rock salt and gypsum, and anhydrite) are correlated with the Wieliczka Fm [44], as well as other salt-bearing formations on the territory of Romania and Slovakia [28]. Potash salts used to be extracted locally in the Kalush area (the Kalush-Holyn deposit) [45]. However, the stratigraphic position and age of the Kalush-Holyn potash salt deposits remains controversial and debated (KarpatianBadenian age?) [42]. That geological situation is complicated because older potassium salts (Vorotyshcha suite) also occur in the inner foredeep of Ukraine, located beneath the Carpathian nappes. Those salts are associated with the lower molasses and used to be extracted in the Stebnik area. The relevant salt-bearing deposits belong to the Early Miocene-Burdigalian stage (Eggenburgian), e.g., [28,43,46,47] (Figure 2). Salt-bearing deposits of the Tyras suite were examined in the core of borehole Hrynivka no. 525. This drilling was made during the exploration of potash salts in the frontal part of the Sambir 
Zone in the Hrynivka area (ca. $12 \mathrm{~km} \mathrm{SE}$ of Kalush). Badenian salts samples were collected for laboratory tests from depth interval 280 to $541 \mathrm{~m}$ (Table S1 in Supplementary Materials).

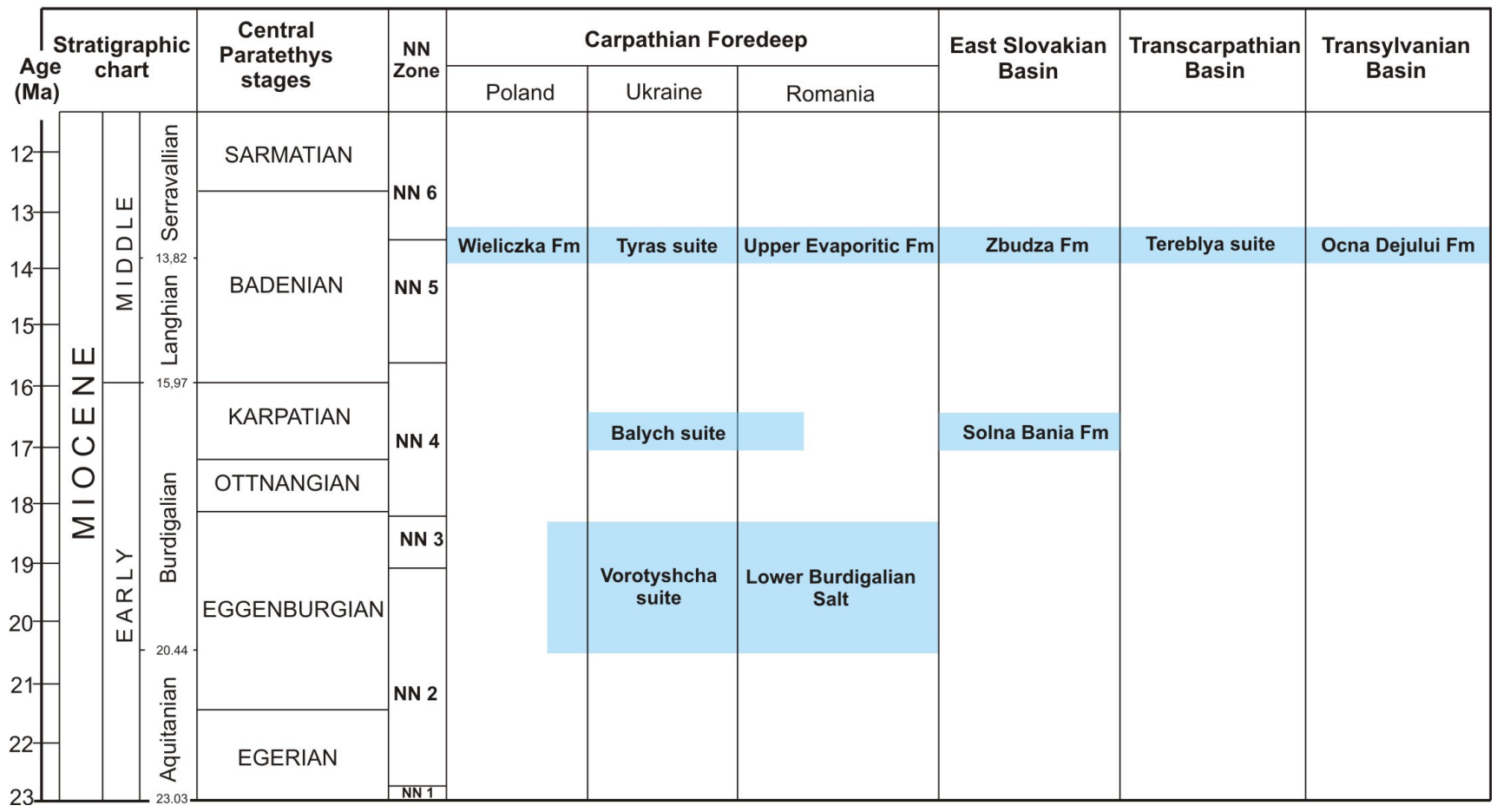

Figure 2. Correlation scheme of salt-bearing formations in Central Paratethys, after [42,43].

Two levels of evaporites occur in the Romanian range of the Carpathians. Older salts of the Lower Miocene (Lower Burdigalian) age occur in the majority of the area of the Eastern Carpathians, e.g., [48]. The original salt thickness is difficult to estimate. The salt bed is probably several hundred meters thick [49]. Anhydrites are occasionally present within the salt layers. Younger salts of the Middle Miocene (Badenian) have been developed as Upper Evaporitic formation or the Ocnele Mari sequence [50]. They represent mostly rock salts ca. $120 \mathrm{~m}$ thick, with thin marl and anhydrite intercalations at the base and marl and clay intercalations on top [2,51]. That salt deposit is mined at Slănic-Prahova (Victoria Salt Mine) [50,51]. A single rock salt sample was collected from the Slănic-Prahova salt mine from strata close to the surface. It is represented by thick layers of salt breccia (Cosmina Breccia) [2] (Table S1 in Supplementary Materials).

In the Transcarpathian Basin, the Badenian evaporites of the Tereblya suite [46] are divided into the lower (terrigenous-anhydrite-gypsum) and upper (salt-bearing) series. The lower series is composed of dark grey anhydrite, with intercalations of clays, siltstones, and sandstones, and also locally of gypsum, tuff, marls, and limestones. The upper Tereblya series consists of rock salt, with intercalations of grey clays, siltstones, and sandstones occasionally. The thickest salt-bearing sediments were identified in the axial south-eastern section of the Back-Carpathian Basin [43]. Samples of the Upper Tereblya suite come from the Solotvyno salt dome (Table S1 in Supplementary Materials). The salt thickness ranges there from several meters to $1400 \mathrm{~m}$, although its primary sedimentation thickness is not more than $500-600 \mathrm{~m}$.

The East-Slovakian Basin is the northernmost section of the extensive Pannonian Basin. It was formed within an intermountain depression, generally in the 'horst-and-graben style' of morphology [52], mainly resulting in syndepositional fault activity. Two evaporite intervals occur there: the lower Solna Bania formation of the Early Miocene age (Karpatian) and the upper Zbudza formation Middle Miocene (Badenian), covering most of the East 
Slovakian Basin area [53,54] (Figure 2). Salt-bearing deposits of the Zbudza Fm contain pure or clayey halites, with nodular anhydrite, interbedded with siliciclastics [25].

Salt-bearing deposits of the Zbudza Fm are analogs of the Tyras suite and Wieliczka Fm from the Carpathian Foredeep (Figure 2). Samples of rock salts come from borehole Ep-2 at a depth interval of 130-246 m [55] (Table S1 in Supplementary Materials).

In the Transylvanian intermountain depression, the Badenian salts occur in almost all areas. Post-depositional salt tectonics determined the present thickness of the salt. Primarily, the top of the salt series is folded, while the base is almost horizontal. About 40 salt structures have been recognized there (e.g., Dej, Turda, Ocna Mureş, Praid, and Sovata), reaching 1000-2000 $\mathrm{m}$ in diapir bodies [23]. They are located in two major, roughly north-south oriented lineaments, situated near the western and eastern borders of the Transylvanian Basin. Diapir structures were developed especially on the eastern side, where diapirism was strongly enhanced by regional tectonics (compressive stress field) and Neogene volcanic activity [56]. The Transylvanian depression was investigated and the rock salt from the Ocna Dej salt dome was sampled, with a total tectonic thickness of $\sim 1800 \mathrm{~m}$ (Table S1 in Supplementary Materials).

The newly discovered massive evaporites from the Soltvadkert Trough in Hungary, $50 \mathrm{~m}$ thick, were described and documented by Baldi et al. [26]. Those evaporite deposits were correlated with other Badenian salt-bearing formations in the Carpathian area. According to micro-paleontological research [57], the salt formation was deposited in the Tuzla Basin in Bosnia and Herzegovina during the Middle Miocene (lower Badenian, calcareous nannoplankton NN5 Zone) [27].

\section{Materials and Methods}

The method of homogenization of inclusions is based on the assumption that the inclusions were trapped as a single, homogeneous phase when the host minerals precipitated. The composition of inclusions was not changed after entrapment, and the volume of the inclusions has remained unchanged until today [3,58-61]. The homogenization temperature (Th) can be recorded during heating of the two-phase (with a captive mineral or gas phase) inclusions into single-phase ones. According to theory [3,62], the temperature represents the minimum temperature of the environment during the mineral formation (in such a case, it was the temperature of brine in the salt basin). However, primary fluid inclusions in the halite can remain single-phase, especially when the temperature of halite crystallization was close to ambient temperature due to metastability and below $40-45{ }^{\circ} \mathrm{C}$ [63]. Thus, a vapour phase had to be artificially induced in the laboratory by sample cooling in a freezer [64].

Moreover, the lower the concentration of brines in the inclusions, the easier it was to obtain the gas phase [65]. When the brine concentration increased to the onset of halite crystallization, the gas phase appeared after $1-2$ days (at the temperature of $0-5^{\circ} \mathrm{C}$ ). When the concentration of brine was close to the stage of potassium salts, crystallization appeared only after 60 days, after halite cooling at the temperature of $-10^{\circ} \mathrm{C}$ [66]. That method was tested on halite crystals grown in laboratory conditions and those collected from modern salt lakes, with satisfactory results [64,67].

In our research, a heat chamber designed by Kalyuzhny [68] was applied. That instrument allowed for the observation of the homogenization processes of a large number of inclusions in halite. Research practice, with the application of such a heating chamber, made it possible to establish the temperature determination accuracy of $\pm 2{ }^{\circ} \mathrm{C}$, in the range from 30 to $250{ }^{\circ} \mathrm{C}$ [62]. To improve the accuracy and quality of measurements, the convenience of working with the thermometric installation, based on the experience of operating previous designs of low-temperature thermal-cryo chambers, has made several modifications to the existing design [69]. In particular, the replacement of the heat chamber material (stainless steel) by copper made it possible to avoid unnecessary thermal gradients in the chamber and increase the permissible heating rate by 20 times, owing to the higher thermal conductivity of copper. For the same purpose, the optical glass windows of the 
camera were replaced by leuco sapphire crystal, representing a significantly higher thermal conductivity. The measuring system of the setup was made on a miniature platinum resistance thermometer with an electronic measurement unit. Those improvements assured high system stability and good reproducibility of measurement results. The temperature value variations during repeated measurements did not exceed $0.1^{\circ} \mathrm{C}$. The chamber was checked for temperature gradients using sulfur, sodium thiosulphate, and ice. Temperature gradients were reduced, and convection air flows in the camera were leveled when we used a plug-in copper camera cover in the form of a cap with a sapphire window. Besides, there was no significant deterioration of the observation conditions.

To study the temperature of homogenization of halite inclusions, 1-2 mm thick plates were prepared. Then, they were wrapped in foil and cooled in sealed containers at the temperatures of $-5{ }^{\circ} \mathrm{C}$ and $-10^{\circ} \mathrm{C}$, for $2-4$ days. When the gas phase appeared in the initial single-phase fluid inclusions, the plates were placed on a sapphire glass slide in the heat chamber. The standard heating rate of the preparation during measurements was $1-2{ }^{\circ} \mathrm{C} / \mathrm{min}$. and it decreased as the homogenization temperature approached $0.2^{\circ} \mathrm{C} / \mathrm{min}$., using a two-stage adjustment.

We studied 10-75 $\mu \mathrm{m}$ fluid inclusions in the near-surface cumulate halite, bottomgrowth chevron halite, and full-faceted cubic halite. Near-surface cumulate halite originated from the brine-air interface and grew in the upper layers of saturated brine due to intense water evaporation [70-72]. We did not find a lot of preserved 'classical' cumulate halite in the Badenian salts of the Carpathian region. Due to halite's fragile and skeletal texture, most crystals were crushed and later served as nuclei for the bottom-growth halite crystals. In the Badenian salts, only rare fragments of cumulate halite textures were found, with numerous fine inclusions (Figure 3A,B). Large inclusions were found there on the background of small ones. Transparent areas without inclusions along the perimeter of large ones were also observed (see Figure 3A,B).

Bottom-growth halite, with zonation (chevron, Figure $3 \mathrm{C}$ ), and halite, with weakly expressed zoning, were noticed (Figure 3D). Full-faceted cubic crystals with stepped faces or strongly elongated lateral faces (rectangular parallelepipeds) were also common. The cross-section in the upper part of the rectangular parallelepipeds resembled the structure of near-surface halite (Figure 3E). However, in the longitudinal section, halite did not have a characteristic V-shape (Figure 3F).

The fluid inclusions of the Badenian salts dominated as a single-phase liquid. Less frequent were two-phased (gas-liquid) inclusions that had originated mainly from overheated salt deposits subjected to re-crystallization during deep burial diagenesis and the tectonic processes related to the formation of the Carpathians [73-76]. There is no notice of captive minerals in fluid inclusions of the studied samples, probably because the brine concentration was too low. The inclusions sometimes contained xenogeneic crystals, terrigenous material, liquid, solid bituminous matter, plant debris, spores, pollen, and algae. The inclusions were in the form of negative cubic crystals, and their sizes often exceeded $150 \mu \mathrm{m}$, sometimes reaching $600 \mu \mathrm{m}$. The length of chevron halite textures was usually from 0.5 to $2.5 \mathrm{~cm}$, sometimes from 7 to $10 \mathrm{~cm}$. Previous studies [63,77] showed that the growth rates of near-bottom halite exceeded the growth rates of halite in modern salt lakes by $2-3$ times and reached $1.15 \mathrm{~mm}$ per day. 


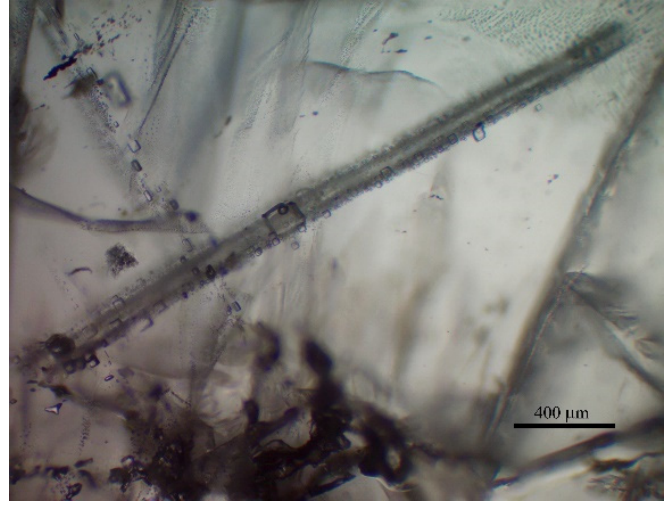

(A)

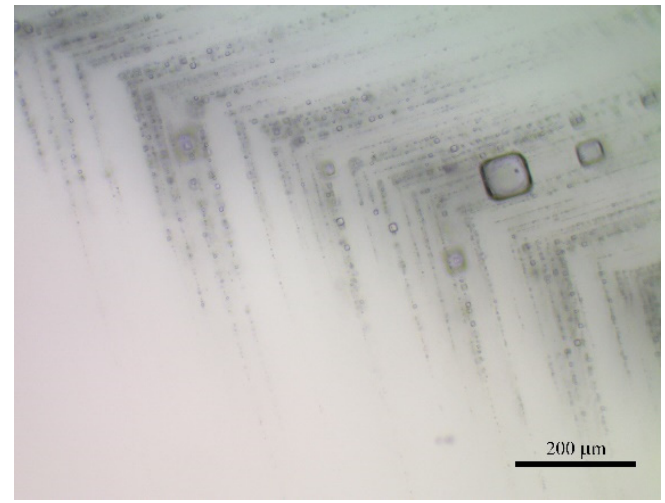

(C)

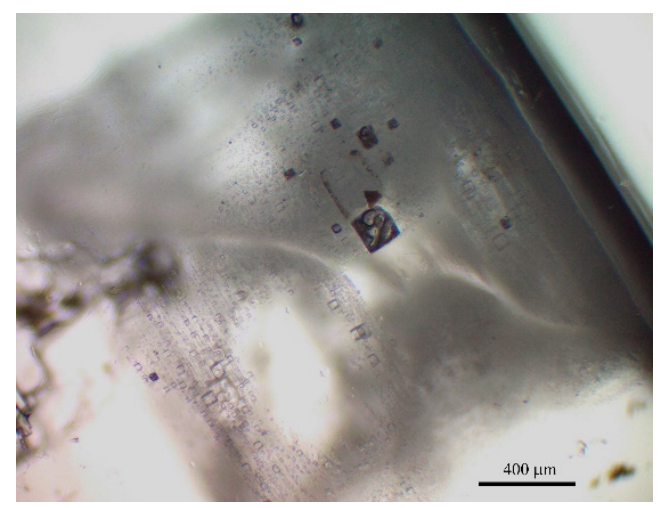

(E)

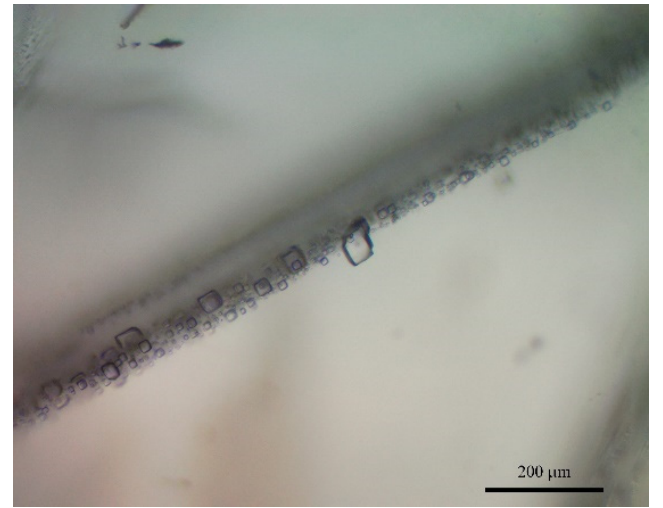

(B)

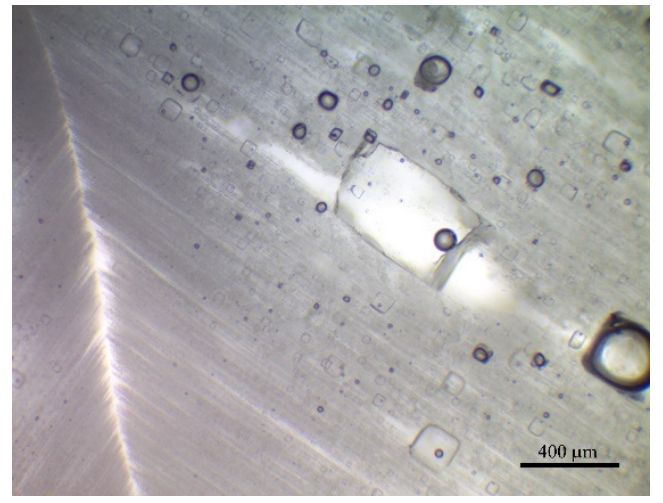

(D)

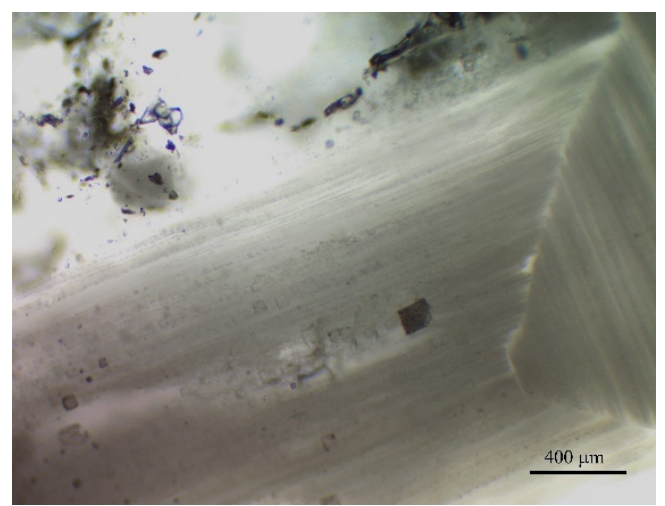

(F)

Figure 3. Sedimentation textures of halite. (A,B) Relics of surface (cumulate) halite: Solotvyno, Mine No. 9, Sample 34; (C-F) bottom-growth (chevron) halite: Mukachevo, Borehole 6-T (C,D); Slănic-Prahova, Sample P-25 (E,F).

\section{Results}

The 435 measurements of homogenization temperatures (Th) of the fluid inclusions in halite, presented in this paper, involved 36 crystals of chevron halite and two crystals of near-surface cumulate halite. We studied inclusions 30-100 $\mu \mathrm{m}$ in size. Commonly, the homogenization temperature values did not depend on the size of the inclusions (excluding the near-surface halite). Information about the type of rock salt and sampling depth from boreholes is indicated in Table S1 (in Supplementary Materials). All our samples represented Badenian salts and came from the Carpathian area: Wieliczka, Hrynivka, Zbudza, Slănic-Prahova, Okna Dej, and Solotvyno (Figure 1). The total range of homogenization temperatures was $13.0-36.0^{\circ} \mathrm{C}$ (Table S1 in Supplementary Materials). 
The homogenization temperatures of the inclusions of the bottom-growth halite were not correlated with inclusion sizes. Within one and the same sample, the inclusions were homogenized in a narrow temperature range. In different samples of near-bottom halites, the ranges of homogenization temperatures of inclusions were somewhat diverse, and the spread of homogenization temperatures did not exceed $9{ }^{\circ} \mathrm{C}$. In reference to the homogenization temperature ranges, one could distinguish two groups of samples. Respective homogenization temperatures were in the ranges from 13.0 to $22.0^{\circ} \mathrm{C}$ (relatively low temperature), and 17.5 to $26.0{ }^{\circ} \mathrm{C}$ (relatively high temperature) (Figure 4 ). The temperature graphs (Figures 4 and 5) show respective groups of the maximum number of measurements (>20), in the intervals from 18.0 to $19.0^{\circ} \mathrm{C}$, and 23.0 to $23.5^{\circ} \mathrm{C}$, in respect of selected groups of samples. The average homogenization temperatures for both groups of samples were, respectively $18.0{ }^{\circ} \mathrm{C}$ (low temperature) and $24.0^{\circ} \mathrm{C}$ (high temperature).
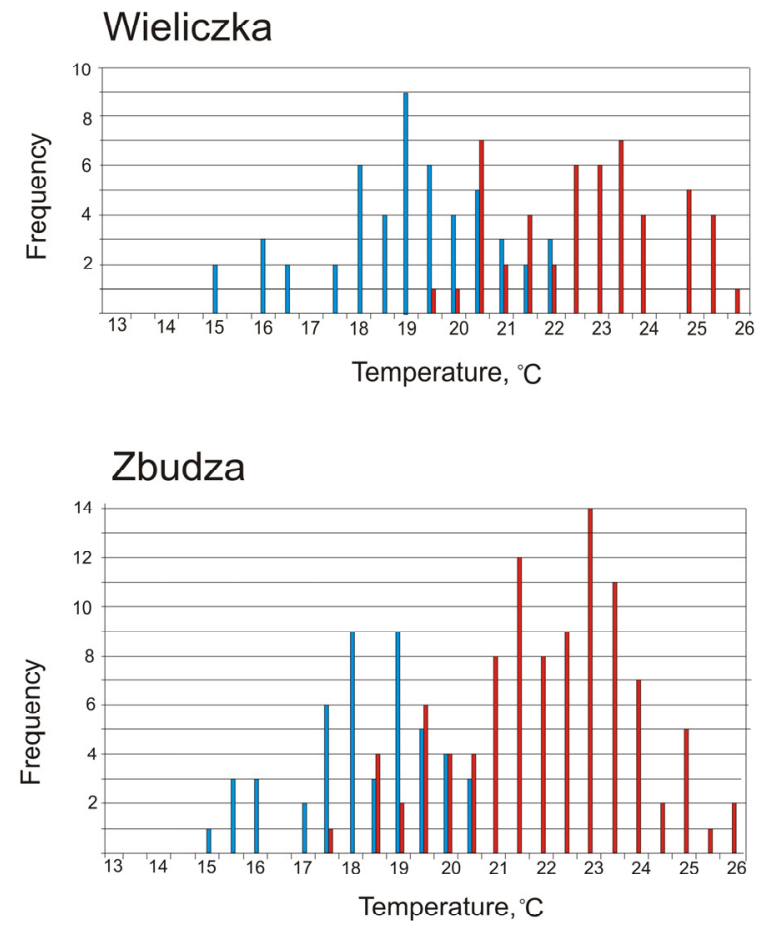
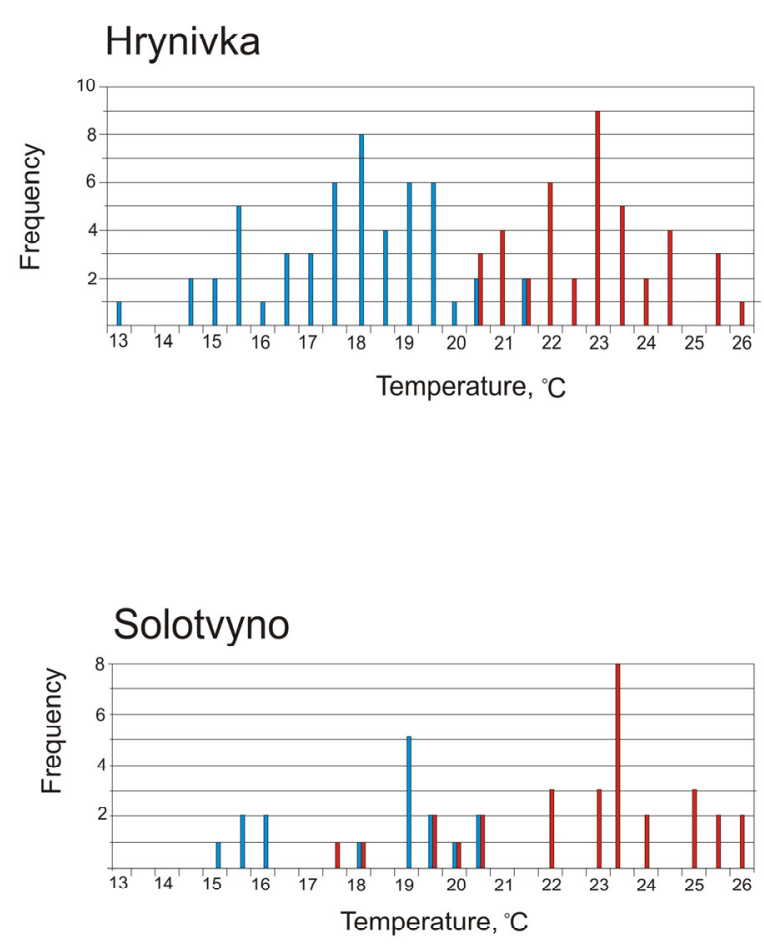

Figure 4. Distribution of the homogenization temperatures of the bottom halite inclusions from Wieliczka Salt Mine, Zbudza, Borehole Ep-2, Hrynivka, Borehole No. 525, and Solotvyno Salt Mine. Colour coding. Blue: temperatures ranging from 13.0 to $22.0^{\circ} \mathrm{C}$ in 18 samples. Red: temperatures are ranging from 17.5 to $26.0^{\circ} \mathrm{C}$ in 18 samples. The precision of the $\mathrm{Th}$ measurement $\left( \pm 0.5^{\circ} \mathrm{C}\right)$.

The homogenization temperatures of inclusions found in the near-surface halite (cumulate texture of halite) ranged from 20.0 to $36.0^{\circ} \mathrm{C}$ (Table S1 in Supplementary Materials). The spread reached $16^{\circ} \mathrm{C}$ in the near-surface halite (samples 116 and 34 from the Solotvyno Salt Mines, Table S1). Thus, the large inclusions of the near-surface halite, which were clearly distinguished on the background of small ones, represented lower homogenization temperatures. 


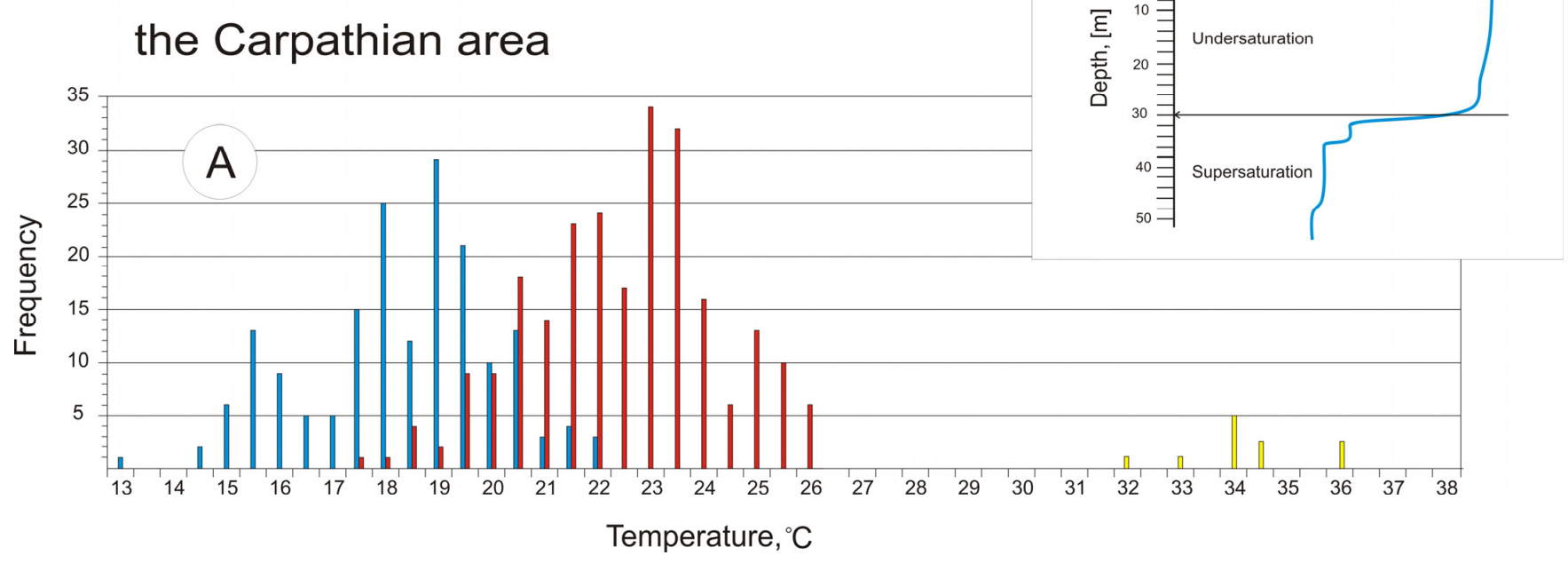

Figure 5. (A) Distribution of the homogenization temperatures of the halite inclusions from the Badenian salt-bearing deposits of the Carpathian area (this study). Colour coding. Blue: temperatures ranging from 13.0 to $22.0^{\circ} \mathrm{C}$ in 18 samples. Red: temperatures are ranging from 17.5 to $26.0^{\circ} \mathrm{C}$ in 18 samples. Yellow: temperatures are ranging from 32.0 to $36.0^{\circ} \mathrm{C}$ in 2 samples of cumulate halite. (B) Distribution of temperatures in the brine of the modern Dead Sea in the summer months (August 2015) [78].

\section{Interpretation and Discussion}

Full-faceted halite forms found in salt-bearing sediments (constituting the overwhelming part of bottom crystals) indicated an insignificant supersaturation of brines due to the frequent growth rates of the edges, tops, and bottom-halite edges leveled off, with stepwise edge growths. In addition, the apparent difference in the sizes of fluid inclusions in cumulate and chevron halites indicated their growth from brines characterized by various concentrations and temperatures [77].

The study of the fluid inclusions occurring in laboratory halite crystals that precipitated from 30 to $40{ }^{\circ} \mathrm{C}$ showed homogenization of gas-liquid inclusions in halite (with a gas phase obtained artificially after halite freezing) had occurred in a specific temperature range $[67,79]$. Thus, based on a sufficiently large number of examinations, the actual temperature of mineral formation was determined in reference to the maximum homogenization temperature value [79] or determined from the last maximum of homogenization temperatures of inclusions $+1{ }^{\circ} \mathrm{C}$ on the histogram of their distribution [67].

Based on that and upon completion of our studies, the temperature ranges of the mineral formation at the bottom of the Badenian salt-bearing basins were determined to be from 19.5 to $22.0^{\circ} \mathrm{C}$ and 24.0 to $26.0{ }^{\circ} \mathrm{C}$ (Figure 5A), and those of the brine surface from 34.0 to $36.0{ }^{\circ} \mathrm{C}$, respectively.

A few near-surface halite nuclei were re-crystallized at the bottom of the basin. Large inclusions of cumulate halites representing low homogenization temperatures (Table S1 in Supplementary Materials) were the inclusions formed in the deposit's bottom environment. That was indicated by the inclusions' shapes, sizes, and locations in the texture. It was obvious that the bottom halite had been formed within cooled saturated surface brines. However, the mechanism of that type of crystallization was not clear.

At present, there are no salt-bearing sea basins on Earth in which the accumulation of thick rock-salt layers would take place. However, the study of the halite crystallization mechanism in modern lakes showed that, similarly to ancient basins, two genetic varieties of sedimentation halite had developed: near-surface (cumulate) and bottom (chevron and 
full-faceted) halites $[63,80,81]$. The zonal structure of the near-bottom crystals developed owing to the uneven flow of saturated brine, caused by the changes in the evaporation rates of the solution and day/night temperatures. The moments of faster growths were found in a larger number of inclusions than those of slower growths [82]. 'Apparently, the most rapid growth occurs in the evening and at night in summer, when the temperature drops and the rapidly cooling upper layers of concentrated brine sink to the bottom' [83].

\subsection{A Model of the Badenian Salt-Bearing Basins without Thermocline}

Under that model, we assumed that the thermal regime of the basins was not the same throughout the water column in the daytime and leveled off at night. Bottom halite grew intensively from cooled supersaturated near-surface brines. Due to rapid cooling in the evening and at night, it became heavier and dropped to the bottom of the basin. The temperature of the bottom brines was not stable, and it was consistently lower than that of the surface brines. Some differences in the temperature ranges of the gas-liquid inclusion homogenization in various investigated chevron halites were explained by various degrees of cooling of the saturated surface brines. Estimated depths of the Badenian salt-bearing basins, obtained earlier in the study of the gas saturation of fluid inclusions, amounted to 6-30 m [63].

\subsection{A Model of a Relative Depth of the Badenian Salt-Bearing Basins with a Pronounced Thermocline}

In the case of such a model, it was the most reasonable to use the data relating to the only contemporary deep salt basin, the Dead Sea, e.g., [78]. The sea is located in the Mediterranean climatic zone where the temperatures rise to $32-45^{\circ} \mathrm{C}$ during the day in summer and drop rapidly to about $20^{\circ} \mathrm{C}$ and less at night. In summer, the upper $25-30 \mathrm{~m}$ of the Dead Sea water column heats up to $34-36^{\circ} \mathrm{C}$. Below that depth, there is a thermocline, where the temperature drops rapidly to $26^{\circ} \mathrm{C}$ at a distance of $2 \mathrm{~m}$. Similar temperatures $\left(\sim 24^{\circ} \mathrm{C}\right)$ were recorded on the Dead Sea floor (Figure 5B). In winter, the temperature of the whole water column is equalized and reaches about $24{ }^{\circ} \mathrm{C}$ [78].

The results of our research on the halite crystallization temperature in the Badenian basins of the Carpathian area are generally consistent with the data on the temperature distribution of the modern Dead Sea. Therefore, by analogy, based on the Dead Sea data [78], we can assume that the thickness of the water column in the Badenian salt basins was about $30 \mathrm{~m}$. As shown in a previous study [81], the presence of bottom-growth halite with irregular zoning was associated with the growth of crystals in the local depressions of the bottom of the basin, where higher-density brines were accumulated. At the same time, rhythmic zoning in halite grew as a result of the influx of surface brine, concentrated during the daytime in deep zones with stable temperatures at the bottom of the basin (Figure 6).

Similar examples of different temperatures of homogenization of inclusions in halite are known from other salt basins. The presence of the so-called 'low temperature' (from 24 to $25^{\circ} \mathrm{C}$ ) or 'high temperature' (from 37.8 to $42.6^{\circ} \mathrm{C}$ ) in the bottom halite of the Permian Upper Pechora Basin [66] can be explained by the crystallization of halite at different depths in a saline basin with a pronounced thermocline. Those two types of halite were found in different sections of the basin and at different hypsometric levels. In the Upper Pechora Basin, homogenization temperature (Th), 'low temperature' (from 10 to $25^{\circ} \mathrm{C}$ ) and 'high temperature' (from 9 to $42.6^{\circ} \mathrm{C}$ ) indicated that halite was formed at various depths in the saline basin with a pronounced thermocline. The temperature range from 10 to $25{ }^{\circ} \mathrm{C}$ was close to that of the investigated halite of the Badenian Basin, which ranged from 13 to $26^{\circ} \mathrm{C}$, and possibly indicated the existence of ancient salt basins with a pronounced thermocline. The crystallization mechanism of the 'high-temperature', near-bottom halite of the Upper Pechora Basin was similar to that which existed in the shallow Permian saline basins in North America, with daily temperature fluctuations from 21.4 to $49.8^{\circ} \mathrm{C}$ [84]. Fluid inclusions in primary chevron halite with homogenization temperatures between $5{ }^{\circ} \mathrm{C}$ and $25^{\circ} \mathrm{C}$, which represent brine temperatures during halite precipitation, were recorded from Silurian Salina Fm by Satterfield et al. [85]. 


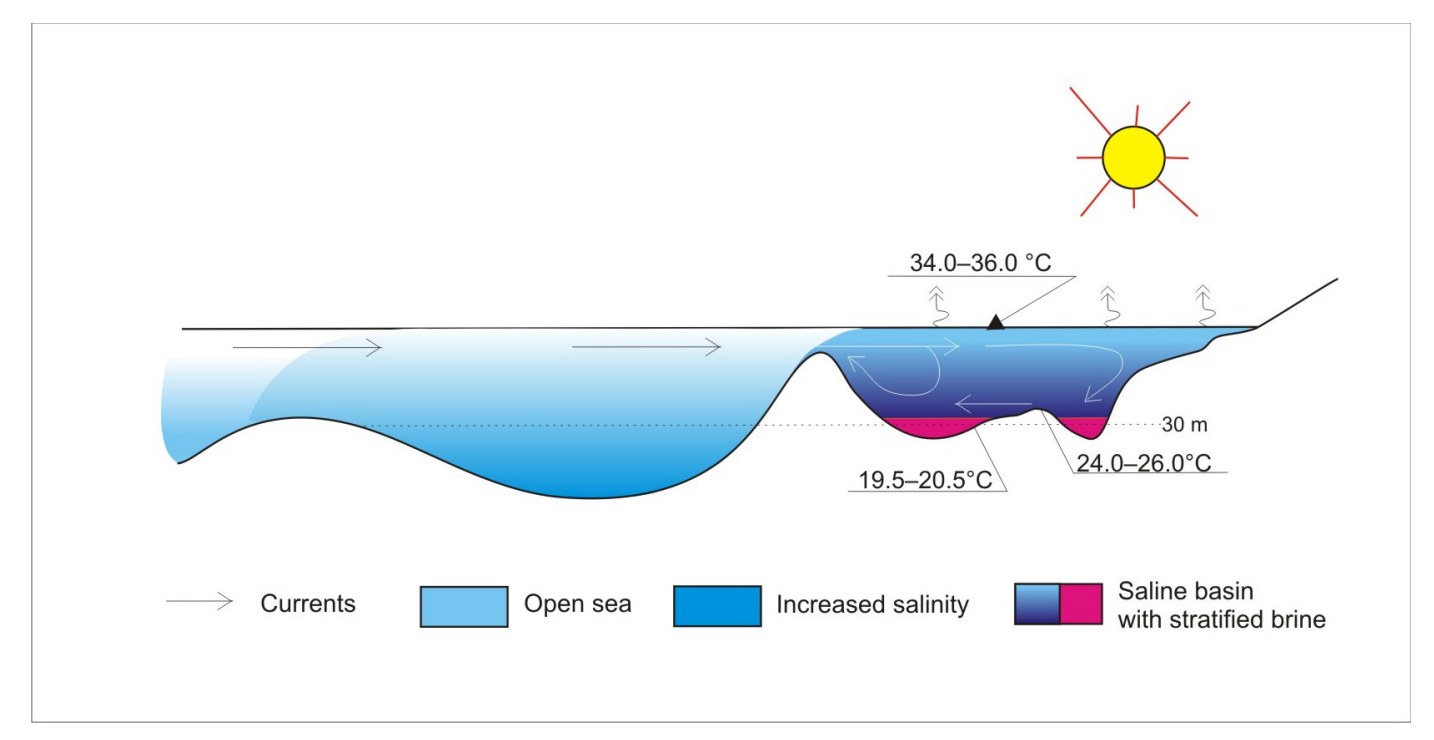

Figure 6. A model of the Badenian saline basin with a pronounced thermocline at depths of about $30 \mathrm{~m}$.

The proposed temperature distribution on the model of the saline basins with a pronounced thermocline (Figure 6) is adequately justified to explain characteristic sedimentation features as gravity mass movements, e.g., submarine slumps, olistostromes, redeposited salt conglomerates, were well documented from Badenian salt deposits $[25,35,86-89]$ and helpful in explaining the paleotemperature data for Paratethys during the Badenian Salinity Crisis $[2,90]$.

The recorded global cooling event of Mi-3b, an age-term from 13.9 to 13.7 Ma [91], related to the rapid expansion of the East Antarctic ice sheet, caused significant climate changes on a global scale and a glacial-eustatic drop of the sea level $[1,16,17]$. The global drop of the sea level limited the outflow of deep, highly salted water from the basins situated within the Carpathian areas [1]. The climate changed from subtropical to temperate in the Carpathian area [31]. However, the mean annual temperature was still relatively high $\left(15-18^{\circ} \mathrm{C}\right)$ [92], similar to the modern Middle East climate. $\mathrm{Mg} / \mathrm{Ca}$ ratio paleothermometry for the planktonic species of foraminifera after the Middle Miocene Climatic Optimum show that the temperature of Central Paratethys seawater's ranges from 24.3 to $25.8^{\circ} \mathrm{C}$ (at depth $\sim 50 \mathrm{~m}$ ) and from 15.4 to $17.3^{\circ} \mathrm{C}$ at the bottom basin ( 400 $\left.\mathrm{m}\right)$ [93].

Our data showed that the climate changes during the global cooling event did not significantly affect the temperature of seawater isolated in the Carpathians' intra-mountain and fore-mountain salt basins. Based on the obtained data on the homogenization temperatures of inclusions, we could use only the data regarding near-surface halite to characterize the air temperature in the Middle-Late Badenian period, from which it could be inferred that the air temperature ranged from 34 to $36{ }^{\circ} \mathrm{C}$ in warm seasons.

\section{Conclusions}

Our research confirmed that paleotemperatures were reconstructed effectively by using the method of preliminary cooling of halite samples containing single-phase fluid inclusions, followed by subsequent homogenization of inclusions. In each studied sample, homogenization of inclusions occurred in a narrow temperature range. For example, the spread of homogenization temperatures did not exceed $9^{\circ} \mathrm{C}$ in the case of chevron halite inclusions. When a sufficiently large number of determinations was available, the accurate mineral formation temperatures were determined based on the maximum value of the homogenization temperature.

It was determined that the chevron bottom halite of the Badenian salt-bearing basins of the Carpathian region crystallized from cooled, supersaturated near-surface brines. Consequently, the temperature of the bottom brines was always lower compared to that of 
the surface brines. On the surface, the temperature ranged from 34.0 to $36.0^{\circ} \mathrm{C}$, and at the bottom of the basin from 19.5 to $22.0^{\circ} \mathrm{C}$ and 24.0 to $26.0^{\circ} \mathrm{C}$. Moreover, the temperatures of the surface brine corresponded to the temperatures of air.

Two models of the halite formation mechanism at the bottom of the basin were proposed:

- Growth of bottom halite from cooled supersaturated near-surface brines, which, due to rapid cooling in the evening and at night, became heavier and dropped to the bottom of the basin.

- Growth of bottom halite in basins with a pronounced thermocline. The model of ancient salt-bearing basins with a pronounced thermocline had a higher priority for explaining all sedimentation features. Some differences in the obtained crystallization temperatures of the bottom halite were associated with crystallization at various depths of the sedimentation basin bottom.

The results presented herein refer to the crystallization temperatures of halite in the Badenian saline basins that comply with the data on the temperature distribution in the water column of the modern deep sea, the Dead Sea.

Supplementary Materials: The following are available online at https:/ /www.mdpi.com/article/10 $.3390 / \min 11080831 / \mathrm{s} 1$ : Table S1 with results of homogenization temperatures.

Author Contributions: Conceptualization, A.R.G. and K.B.; methodology, A.R.G. and I.M.Z.; formal analysis, A.R.G.; investigation, A.R.G. and F.M. resources, A.R.G. and I.M.Z.; writing-original draft preparation, A.R.G. and K.B.; writing-review and editing, A.R.G. and K.B.; project administration, F.M.; funding acquisition, K.B. and F.M. All authors have read and agreed to the published version of the manuscript.

Funding: This work was supported by the research grant no 16.16.140.315 from the AGH University of Science and Technology.

Data Availability Statement: Not applicable.

Acknowledgments: We are grateful to the journal referees for their comments.

Conflicts of Interest: The authors declare no conflict of interest.

\section{References}

1. De Leeuw, A.; Bukowski, K.; Krijgsman, W.; Kuiper, K.F. Age of the Badenian salinity crisis; impact of Miocene climate variability on the circum-Mediterranean region. Geology 2010, 38, 715-718. [CrossRef]

2. Peryt, T.M. The beginning, development and termination of the Middle Miocene Badenian salinity crisis in Central Paratethys. Sediment. Geol. 2006, 188-189, 379-396. [CrossRef]

3. Roedder, E. The fluids in salt. Am. Mineral. 1984, 69, 413-439.

4. Hollister, L.S.; Crawford, M.L.; Roedder, E.; Burruss, R.C.; Spooner, E.T.C.; Touret, J. Practical aspects of microthermometry. Mineral. Assoc. Can. Short Course 1981, 6, 13-38.

5. Shepherd, T.J.; Rankin, A.H.; Alderton, D.H.M. A Practical Guide to Fluid Inclusion Studies; Blackie \& Son: Glasgow, UK, 1986; 239p.

6. Goldstein, R.H.; Reynolds, T.J. Systematics of fluid inclusions in diagenetic minerals. SEPM Short Course 1994, 31, 199.

7. Goldstein, R.H. Petrographic analysis of fluid inclusions. Mineral. Assoc. Can. Short Course 2003, 32, 9-53.

8. Bodnar, R.J. Introduction to fluid inclusions. Mineral. Assoc. Can. Short Course 2003, 32, 1-8.

9. Zambito, J.; Benison, K. Extremely high temperatures and paleoclimate trends recorded in Permian ephemeral lake halite. Geology 2013, 41, 587-590. [CrossRef]

10. Zhang, H.; Lü, F.; Mischke, S.; Fan, M.; Zhang, F.; Liu, C. Halite fluid inclusions and the late Aptian sea surface temperature the Congo Basin, northern South Atlantic Ocean. Cretac. Res. 2017, 71, 85-95. [CrossRef]

11. Xu, Y.; Liu, C.; Cao, Y.; Zhang, H. Quantitative temperature recovery from middle Eocene halite fluid inclusions in the easternmost Tethys realm. Int. J. Earth Sci. Geol. Rundsch. 2018. [CrossRef]

12. Li, M.; Sun, S.; Yan, M.; Meng, F.; Fang, X.; Song, X.; Zhu, L. Late Cretaceous paleoclimate reconstruction from halite in an evaporite deposit on the Khorat Plateau, Laos. Cretac. Res. 2020, 116, 104589. [CrossRef]

13. Papp, A.; Cicha, I. Definition der Zeiteinheit M [4]-Badenien. Chronostratigraphie Und Neostratotypen Miozän Zent. Paratethys 1978, $6,47-48$.

14. Hohenegger, J.; Ćorić, S.; Wagreich, M. Timing of the Middle Miocene Badenian Stage of the Central Paratethys. Geol. Carpathica 2014, 65, 55-56. [CrossRef] 
15. Abels, H.A.; Hilgen, F.J.; Krijgsman, W.; Kruk, R.W.; Raffi, I.; Turco, E.; Zachariasse, W.J. Long-period orbital control on middle Miocene global cooling. Integrated stratigraphy and astronomical tuning of the Blue Clay Formation on Malta. Paleoceanography 2005, 20, 1-17. [CrossRef]

16. John, C.M.; Karner, G.D.; Browning, E.; Leckie, R.M.; Mateo, Z.; Carson, B.; Lowery, C. Timing and magnitude of Miocene eustasy derived from the mixed siliciclastic-carbonate stratigraphic record of the northeastern Australian margin. Earth Planet. Sci. Lett. 2011, 304, 455-467. [CrossRef]

17. Simon, D.; Palcu, D.; Meijer, P.; Krijgsman, W. The sensitivity of middle Miocene paleoenvironments to changing marine gateways in Central Europe. Geology 2019, 47, 35-38. [CrossRef]

18. Palcu, D.V.; Golovina, L.A.; Vernyhorova, Y.V.; Popov, S.V.; Krijgsman, W. Middle Miocene paleoenvironmental crises in Central Eurasia caused by changes in marine gateway configuration. Glob. Planet. Chang. 2017, 158, 57-71. [CrossRef]

19. Peryt, D.; Gedl, P.; Peryt, T.M. Marine transgression(s) to evaporite basin: The case of middle Miocene (Badenian) gypsum in the Central Paratethys, SE Poland. J. Palaeogeogr. 2020, 9, 16. [CrossRef]

20. De Leeuw, A.; Tulburec, M.; Kuiper, K.F.; Melinte-Dobrinescu, M.C.; Stoica, M.; Krijgsman, W. New 40Ar/39Ar, magnetostratigraphic and biostratigraphic constraints on the termination of the Badenian salinity crisis: Indications for tectonic improvement of basin interconnectivity in southern Europe. Glob. Planet. Chang. 2018, 169, 1-15. [CrossRef]

21. Śliwiński, M.; Babel, M.; Nejbert, K.; Olszewska-Nejbert, D.; Gasiewicz, A.; Schreiber, B.C.; Be-Nowitz, J.A.; Layer, P. BadenianSarmatian chronostratigraphy in the Polish Carpathian Foredeep. Palaeogeogr. Palaeoclimatol. Palaeoecol. 2012, 326-328, 12-29. [CrossRef]

22. Garlicki, A. Sedimentation of Miocene Salts in Poland; Prace Geologiczne PAN: Kraków, Poland, 1979; Volume 119. (In Polish with English Summary)

23. Krézsek, C.s.; Filipescu, S. Middle to Late Miocene sequence stratigraphy of the Transylvanian Basin (Romania). Tectonophisics 2005, 410, 437-463. [CrossRef]

24. Krézsek, C.; Bally, A.W. The Transylvanian Basin (Romania) and its relation to the Carpathian fold and thrust belt: Insights in gravitational salt tectonics. Mar. Pet. Geol. 2006, 23, 405-442. [CrossRef]

25. Bukowski, K.; Czapowski, G.; Karoli, S.; Babel, M. Sedimentology and geochemistry of the Middle Miocene (Badenian) saltbearing succession from East Slovakian Basin (Zbudza Formation). In Evaporites through Space and Time; Schreiber, B.C., Lugli, S., Babel, M., Eds.; Special Publications; Geological Society: London, UK, 2007; Volume 285, pp. 247-264.

26. Báldi, K.; Velledits, F.; Ćorić, S.; Lemberkovics, V.; Lõrincz, K.; Shevelev, M. Discovery of the Badenian evaporites in side the Carpathian Arc: Implications for global climate change and Paratethys salinity. Geol. Carpathica 2017, 68, 193-206. [CrossRef]

27. Ćorić, S.; Vrabac, S.; Ferhatbegović, Z.; Đulović, I. Biostratigraphy of Middle Miocene Sediments from the Tuzla Basin (Northeastern Bosnia) Based on Foraminifera and Calcareous Nannoplankton. Neogene Cent. South East. Eur. 2007, 2, 21-23.

28. Khrushchov, D.P. Lithology and Geochemistry of Saliferous Formations of the Carpathian Foredeep; Naukova Dumka: Kyiv, Ukraine, 1980; pp. 1-316. (In Russian)

29. Rögl, F. Palaeogeographic considerations for Mediterranean and Paratethys Seaways (Oligocene to Miocene). Ann. Des. Nat. Mus. Wien 1998, 99A, 279-310.

30. Babel, M. Badenian Evaporite Basin of the Northern Carpathian Foredeep as a Drawdown Salina Basin. Acta Geol. Pol. 2004, 54, 313-337.

31. Kovač, M.; Hudáčková, N.; Halásová, E.; Kováčová, M.; Holcová, K.; Oszczypko-Clowes, M.; Báldi, K.; Less, G.; Nagymarosy, A.; Ruman, A.; et al. The Central Paratethys palaeoceanography: A water circulation model based on microfossil proxies, climate, and changes of depositional environment. Acta Geol. Slovaca 2017, 9, 75-114.

32. Oszczypko, N.; Krzywiec, P.; Popadyuk, I.; Peryt, T. Carpathian Foredeep Basin (Poland and Ukraine). Its Sedimentary, Structural, and Geodynamic Evolution. AAPG Mem. 2006, 84, 261-318.

33. Burov, V.S.; Glushko, V.V.; Pishvanova, L.S. Neogene deposits of the Precarpathian Trough. Geological structure and fossil fuels of the Ukrainian Carpathians. Tr. Ukr. NIGRI 1971, 25, 42-54. (In Russian)

34. Vyalov, O.S. Stratigraphy of Neogene Molasses of the Ciscarpathian Trough; Naukova Dumka: Kyiv, Ukraine, 1965; pp. 1-58. (In Russian)

35. Bukowski, K. Badenian Saline Sedimentation between Rybnik and Dębica Based on Geochemical, Isotopic, and Radiometric Research. Diss. Monogr. 2011, 236, 1-184. (In Polish with English Summary)

36. Krzywiec, P.; Bukowski, K.; Oszczypko, N.; Garlicki, A. Structure and Miocene evolution of the Gdów tectonic "embayment" (Polish Carpathian Foredeep)—A new model based on reinterpreted seismic data. Geol. Q. 2012, 56, 907-920. [CrossRef]

37. Poborski, J. Złoże solne Bochni na tle geologicznym okolicy. Biul. Państw. Inst. Geol. 1952, 78, 1-160. (In Polish with English Summary)

38. Gaweł, A. Budowa geologiczna złoża solnego Wieliczki. Prace Inst. Geol. 1962, 30, 305-331. (In Polish with English Summary)

39. Czapowski, G.; Bukowski, K. Geology and resources of salt deposits in Poland: The state of the art. Geol. Q. 2010, 54, 509-518.

40. Bukowski, K. Comparison of the Badenian saliferous series from Wieliczka and Bochnia in the light of new data. Prace Panstw. Inst. Geol. 1999, 168, 43-56. (In Polish with English Summary)

41. Rowan, M.; Krzywiec, P.; Bukowski, K.; Przybyło, J. Nature and origin of large-scale and intrasalt deformation within the Wieliczka salt mine, Poland. Geol. Q. 2020, 64, 819-837. [CrossRef] 
42. Hryniv, S.P.; Dolishniy, B.V.; Khmelevska, O.V.; Poberezhskyy, A.V.; Vovnyuk, S.V. Evaporites of Ukraine: A review. In Evaporites through Space and Time; Schreiber, B.C., Lugli, S., Babel, M., Eds.; Special Publications; Geological Society: London, UK, 2007; Volume 285, pp. 309-334.

43. Korenevskiy, S.M.; Zaharova, V.M.; Shamahov, V. Miocene Saliferous Formations of the Carpathian Foredeep; Nedra: Leningrad, Russia, 1997; pp. 1-248. (In Russian)

44. Andreyeva-Grigorovich, A.S.; Oszczypko, N.; Savitskaya, N.A.; Ślączka, A.; Trofimovich, N.A. Correlation of Late Badenian salts of the Wieliczka, Bochnia and Kalush areas (Polish and Ukrainian Carpathian Foredeep). Ann. Soc. Geol. Pol. 2003, 73, 67-89.

45. Bukowski, K.; Czapowski, G. Salt geology and mining traditions: Kalush and Stebnyk mines (Fore-Carpathian region, Ukraine). Geotourism Geoturystyka 2009, 3, 27-34. [CrossRef]

46. Pishvanova, L.S. New microfaunistic zone in the Fore-Carpathian region-The Giobigerina bollii zone. Bul. MOIP. Dept. Geol. 1966, 41, 94-97. (In Russian)

47. Peryt, T.M.; Kovalevich, V.M. Association of redeposited salt breccias and potash evaporites in the lower Miocene of Stebnyk (Carpathian Foredeep, West Ukraine). J. Sediment. Res. 1997, A67, 913-922.

48. Schleder, Z.; Tamas, D.M.; Krezsek, C.; Arnberger, K.; Tulucan, A. Salt tectonics in the Bend Zone segment of the Carpathian fold and thrust belt, Romania. Int. J. Earth Sci. 2019, 108, 1595-1614. [CrossRef]

49. Stefanescu, M.; Dicea, O.; Tari, G. Influence of extension and compression on salt diapirism in its type area, East Carpathian Bend area, Romania. In Salt, Shale and Igneous Diapirs in and around Europe; Vendeville, B.C., Mart, Y., Vigneresse, J.L., Eds.; Geological Society: London, UK, 2000; pp. 131-147.

50. Har, N.; Barbu, O.; Codrea, V.; Petrescu, I. New data on the mineralogy of the salt deposit from Slănic Prahova (Romania). Studia Univ. Babeş Bolyai Geol. 2006, 51, 29-33. [CrossRef]

51. Bojar, A.-V.; Barbu, V.; Wojtowicz, A.; Bojar, H.-P.; Hałas, S.; Duliu, O.G. Miocene Slănic Tuff, Eastern Carpathians, Romania, in the Context of Badenian Salinity Crisis. Geosciences 2018, 8, 73. [CrossRef]

52. Vass, D.; Elečko, M.; Janočko, J.; Karoli, S.; Pereszlenyi, M.; Slávik, J.; Kaličiak, M. Paleogeography of the East-Slovakian Basin. Slovak Geol. Mag. 2000, 6, 377-407.

53. Vass, D.; Čverčko, J. Litostratigrafické jadnotky neogénu východoslovenskej nížiny. Geologicke Práce Správy Bratisl. 1985, 82, 111-116. (In Slovak)

54. Karoli, S.; Janočko, J.; Kotulák, P.; Verdon, P. Sedimentology of Karpatian evaporites in the East-Slovakian Basin (Slovakia). Slovak Geol. Mag. 1997, 3, 201-211.

55. Galamay, A.R.; Karoli, S. Geochemistry of the Badenian salts from the East Slovakian Basin, Slovakia. Slovak Geol. Mag. 1997, 3 , 187-192.

56. Har, N.; Rusz, O.; Codrea, V.; Barbu, O. New data on the mineralogy of the salt deposit from Sovata (Mureş County-Romania). Carpathian J. Earth Environ. Sci. 2010, 5, 127-135.

57. Gašparič, R.; Hyžný, M.; Jovanović, G.; Ćorić, S.; Vrabac, S. Middle Miocene decapod crustacean assemblage from the Tuzla Basin (Tušanj, Bosnia and Herzegovina), with a description of two new species and comparison with coeval faunas from Slovenia. Palaeontol. Electron. 2019, 1-21. [CrossRef]

58. Bodnar, R.J.; Vityk, M.O. Interpretation of microthermometric data for $\mathrm{NaCl}-\mathrm{H}_{2} \mathrm{O}$ fluid inclusions. In Fluid Inclusions in Minerals: Methods and Applications; Virginia Polytechnic Institute State University: Blacksburg, VA, USA, 1994; pp. 117-131.

59. Bodnar, R.J. Reequilibration of fluid inclusions. Fluid Incl. Anal. Interpret. Short Course 2003, 32, $213-231$.

60. Yang, L.Q.; Deng, J.; Wang, Z.L.; Zhang, L.; Goldfarb, R.J.; Yuan, W.M.; Weinberg, R.F.; Zhang, R.Z. Thermochronologic constraints on evolution of the Linglong Metamorphic Core Complex and implications for gold mineralization: A case study from the Xiadian gold deposit, Jiaodong Peninsula, eastern China. Ore Geol. Rev. 2016, 72, 165-178. [CrossRef]

61. Galamay, A.R.; Meng, F.; Bukowski, K.; Lyubchak, A.; Zhang, Y.; Ni, P. Calculation of salt basin depth using fluid inclusions in halite from the Ordovician Ordos basin in China. Geol. Q. 2019, 63, 619-628. [CrossRef]

62. Kovalevych, V.M. Physicochemical Conditions of Salt Formation in the Stebnik Potash Deposit; Naukova Dumka: Kyiv, Ukraine, 1978; pp. 1-100. (In Russian)

63. Petrichenko, O.I. Physico-Chemical Conditions of Sedimentation in Ancient Salt-Bearing Basins; Naukova Dumka: Kyiv, Ukraine, 1988; pp. 1-128. (In Russian)

64. Roberts, S.M.; Spencer, R.J. Paleotemperatures preserved in fluid inclusions in halite. Geochim. Cosmochim. Acta 1995, 59, 3929-3942. [CrossRef]

65. Galamay, A.R.; Sidor, D.; Lyubchak, O. Peculiarities of the appearance of the gas phase in single-phase liquid inclusions in halite (to determine the temperature of its crystallization). VIII Sciences. In Proceedings of the Mineralogy: Present and Future, Lviv-Chinadiyeve, Lviv, Ukraine, 11-14 September 2014; pp. 34-36. (In Ukrainian)

66. Shanina, S.N.; Sokerina, N.V.; Galamay, A.R.; Ledentsov, V.N.; Onosov, D.V. Homogenizing temperature test for halite from Yakshinskoe deposit. Vestn. I.G. Komi SC UB R.A.S. 2014, 8, 3-6. (In Russian with English Summary)

67. Acros, D.; Ayora, C. The use of fluid inclusions in halite as environmental thermometer: An experimental study. In Proceedings of the European Current Research on Fluid Inclusions, Nancy, France, 1-4 July 1997; Boiron, M.C., J. Pironon, J., Eds.; Université de Lorraine-CNRS: Nancy, France, 1997; pp. 10-11.

68. Kalyuzhny, V.A. Methods of Studying Multiphase Inclusions in Minerals; Academy of Sciences of the USSR: Kyiv, Ukraine, 1960; pp. 1-169. (In Russian) 
69. Zinchuk, I.M. Geochemistry of Mineral-Forming Solutions of Gold-Polymetallic Ore Occurrences of Central Donbas (According to Inclusions in Minerals). Ph.D. Thesis, IGGGK NAS of Ukraine, Lviv, Ukraine, 2003.

70. Dellwig, L.F. Origin of the Salina salt of Michigan. J. Sed. Petrol. 1955, 25, 83-110.

71. Lowenstein, T.K.; Hardie, L.A. Criteria for the recognition of salt-pan evaporates. Sedimentology 1985, 32, 627-644. [CrossRef]

72. Davis, D.; Lowenstein, T.; Spencer, R. Melting behavior of fluid inclusions in laboratory-grown halite crystals in the systems $\mathrm{NaCl}-\mathrm{H}_{2} \mathrm{O}, \mathrm{NaCl}-\mathrm{KCl}-\mathrm{H}_{2} \mathrm{O}, \mathrm{NaCl}-\mathrm{MgCl}_{2}-\mathrm{H}_{2} \mathrm{O}$, and NaCl-CaCl $2-\mathrm{H}_{2} \mathrm{O}$. Geochim. Cosmochim. Acta 1990, 54, 591-601. [CrossRef]

73. Galamay, A.R.; Bukowski, K.; Poberezhskyy, A.V.; Karoli, S.; Kovalevich, V.M. Origin of the Badenian salt from East Slovakian basin indicated by based on the analysis of fluid inclusions. Ann. Soc. Geol. Pol. 2004, 74, 267-276.

74. Shaidetska, V.S. The geochemistry of Neogene evaporites of Transcarpathian troughin Ukraine. Slovak Geol. Mag. 1997, 3, 193-200.

75. Bukowski, K.; Galamay, A.R.; Krzywiec, P.; Maksym, A. Geochemical Data and Fluid Inclusion Study of the Middle Miocene Halite from Deep Borehole Huwniki-1, Situated in the Inner Zone of the Carpathian Foredeep in Poland. Minerals 2020, 10, 1113. [CrossRef]

76. Galamay, A.R.; Bukowski, K. Chemical composition of Badenian brines from primary fluid inclusions in halite (Transcarpathian Basin, Ukraine). Geol. Kwart. A.G.H. 2011, 37, 245-267. (In Polish with English Summary)

77. Petrichenko, O.I. Methods of Study of Inclusions in Minerals of Saline Deposits; Naukova Dumka: Kyiv, Ukraine, 1973 ; pp. 1-90.

78. Sirota, I.; Enzel, Y.; Lensky, N.G. Temperature seasonality control on modern halite layers in the Dead Sea: In situ observations. G.S.A. Bull. 2017, 129, 1181-1194. [CrossRef]

79. Lowenstein, T.; Li, J.; Brownet, C. Paleotemperatures from fluid inclusions in halite: Method verification and a 100,000 years paleotemperature record, Death Valley, CA. Chem. Geol. 1998, 150, 223-245. [CrossRef]

80. Valyashko, M.G. Halite, its main varieties found in salt lakes, and their structure. Tr. Vses. Mauchno-Issled. Inst. Galurgii 1952, 23, 25-32. (In Russian)

81. Galamay, A.R.; Bukowski, K.; Sydor, D.V.; Meng, F. The Ultramicrochemical Analyses (UMCA) of Fluid Inclusions in Halite and Experimental Research to Improve the Accuracy of Measurement. Minerals 2020, 10, 823. [CrossRef]

82. Valiashko, M.G. The Principle of Forming of Salt Deposits; M.G.U.: Moscow, Russia, 1962; 396p. (In Russian)

83. Strakhov, N.M. Principles of Lithogenesis; Springer: Berlin/Heidelberg, Germany, 2014.

84. Benison, K.C.; Goldstein, R.H. Permian paleoclimate data from fluid inclusions in halite. Chem. Geol. 1999, 154, 113-132. [CrossRef]

85. Satterfield, C.L.; Lowenstein, T.K.; Russell, V.; Vreeland, R.; Rosenzweig, W.D. Paleobrine Temperatures, Chemistries, and Paleoenvironments of Silurian Salina Formation F-1 Salt, Michigan Basin, USA, from Petrography and Fluid Inclusions in Halite. J. Sediment. Res. 2005, 75, 534-546. [CrossRef]

86. Bukowski, K. Sedimentation of clastic strata associated with Miocene salts in Wieliczka (Southern Poland). Slovak Geol. Mag. 1997, 3, 157-164.

87. Ślączka, A.; Kolasa, K. Resedimented salt in the Northern Carpathians Foredeep (Wieliczka, Poland). Slovak Geol. Mag. 1997, 3 , 135-155.

88. Gonera, M.; Bukowski, K.; D’Obryn, K.; Wiewiórka, J. Foraminifera in slump deposits of the Badenian (middle Miocene) Green Stratified Salt in Wieliczka, Poland. Geol. Q. 2012, 56, 869-880. [CrossRef]

89. Głuszyński, A.; Aleksandrowski, P. A deep paleovalley in the floor of the Polish Carpathian Foredeep basin near Pilzno and its control on Badenian (Middle Miocene) evaporite facies. Geol. Q. 2016, 60, 493-516.

90. Gonera, M.; Bukowski, K. Isotopic events in the Early/Middle Badenian (Miocene) of the Upper Silesia Basin (Central Paratethys). Geol. Q. 2012, 56, 561-568. [CrossRef]

91. Hilgen, F.J.; Lourens, L.J.; Van Dam, J.A.; Beu, A.G.; Boyes, A.F.; Cooper, R.A.; Krijgsman, W.; Ogg, J.G.; Piller, W.E.; Wilson, D.S. The Neogene period. In The Geologic Time Scale 2012; Gradstein, F.M., Ogg, J.G., Schmitz, M., Ogg, G., Eds.; Elsevier: Amsterdam, The Netherlands, 2012.

92. Böhme, M. The Miocene Climatic Optimum: Evidence from ectothermic vertebrates of Central Europe. Palaeogeogr. Palaeoclimatol. Palaeoecol. 2003, 195, 389-401. [CrossRef]

93. Scheiner, F.; Holcová, K.; Milovský, R.; Kuhnert, H. Temperature and isotopic composition of seawater in the epicontinental sea (Central Paratethys) during the Middle Miocene Climate Transition based on $\mathrm{Mg} / \mathrm{Ca}, \delta^{18} \mathrm{O}$ and $\delta^{13} \mathrm{C}$ from foraminiferal tests. Palaeogeogr. Palaeoclimatol. Palaeoecol. 2018, 495, 60-71. [CrossRef] 